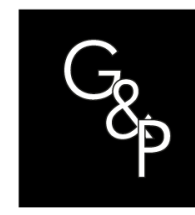

\title{
Simulation-based analysis of shared manufacturing systems
}

\section{Análise baseada em simulação de sistemas de produção compartilhada}

\author{
Gustavo Furtado da Silva ${ }^{1}$ (1), Nelson Casarotto Filho ${ }^{1}$, Enzo Morosini Frazzon ${ }^{1}$ \\ ${ }^{1}$ Universidade Federal de Santa Catarina - UFSC, Centro Tecnológico - CTC, Departamento de Engenharia de \\ Produção e Sistemas - DEPS, Programa de Pós-graduação em Engenharia de Produção - PPGEP, Campus \\ Universitário Reitor João David Ferreira Lima, Florianópolis, SC, Brasil. E-mail: gustavofurtado2@gmail.com; \\ nelson.casarotto@ufsc.br; enzo.frazzon@ufsc.br
}

How to cite: Silva, G. F., Casarotto Filho, N., \& Frazzon, E. M. (2020). Simulation-based analysis of shared manufacturing systems. Gestão \& Produção, 27(1), e3718. http://dx.doi.org/10.1590/0104$530 \times 3718-20$

\begin{abstract}
Advancements in information and communication technologies are encouraging researches in shared manufacturing systems, especially on current high-competitiveness and low-resources scenarios. This paper aims to compare productive resources sharing with traditional manufacturing systems by using a simulation-based optimization model. The model is based on the One Product Integrated Manufacturing paradigm in which the efficiency optimization is pursued by designing ad-hoc virtual factories allocating the best resources available on an existing network. The proposed simulation-based optimization model is capable of identifying the best production path and plan for different distances between network members. Along with a better overall efficiency, it is also possible to argue that dedicated virtual factories ease the identification of problems and allow for improvements without negatively affecting other resources.
\end{abstract}

Keywords: Shared manufacturing; One Product Integrated Manufacturing; Virtual enterprises; Simulation; Optimization.

Resumo: Os avanços em tecnologia de informação e comunicação têm incentivado a pesquisa em sistemas de produção compartilhada, especialmente em cenários de alta competitividade e escassez de recursos. Este artigo visa comparar o compartilhamento de recursos produtivos com sistemas de produção tradicionais através de um modelo de otimização baseado em simulação. O modelo é baseado no sistema One Product Integrated Manufacturing, que busca a otimização da eficiência de um produto através da concepção de fábricas virtuais formadas pelos melhores recursos disponíveis na rede. O modelo de otimização baseado em simulação proposto é capaz de identificar a melhor rota e planejamento de produção em função das diferentes distâncias entre os parceiros da rede. Além de uma melhor eficiência global, também pode ser levantado o ponto de que fábricas virtuais dedicadas facilitam a identificação de problemas e permitem melhorias pontuais sem afetar negativamente os outros recursos.

Palavras-chave: Produção compartilhada; One Product Integrated Manufacturing; Empresas virtuais; Simulação; Otimização.

Received Jan. 5, 2017 - Accepted Aug. 31, 2017

Financial support: CAPES (Coordenação de Aperfeiçoamento de Pessoal de Nível Superior). 


\section{Introduction}

Small and medium enterprises (SMEs) are usually more agile and flexible than large businesses, but they lack the competence to dominate all stages of the value chain (Casarotto \& Pires, 2001). A big advantage of large businesses is possessing conditions to dominate production, logistics, research and development and marketing stages. The formation of cooperation networks might be a competitive alternative to SMEs, so that they can compete with larger companies without losing the characteristics that value them, such as flexibility and agility. Therefore, several different types of business networks such as clusters have formed, especially in developed countries (Santos \& Varvakis, 1999; Alexander et al., 2013). These collaborative production systems and cooperative development environments have gained importance especially for SMEs with limited resources (Brettel et al., 2014).

Business interaction creates synergies and economic benefits through their shared access to supplies, distributors, markets, etc. The organization of the network promotes the development of relationships in which interactions depend on the behavior of agents (Saraceni et al., 2015). Within a collaborative network, risks can be balanced and the combined resources can extend the reach of perceived market opportunities. The network organization multiplies the available capacities without the need for additional investment. As a result, companies in collaborative networks can adapt to volatile markets and shorten the product lifecycle with higher agility (Brettel et al., 2014).

Virtual enterprises are temporary alliances of independent companies that are supported by computer networks and created to exploit market opportunities though the exchange costs, risks, resources, skills and competencies (Brettel et al., 2014; Camarinha-Matos \& Afsarmanesh, 2013). While traditional organizations have physical limitations, virtual organizations are more dynamic and flexible, they can be reconfigured, optimized, and adapted faster to the continuous changes of the market (Tang et al., 2002). This research is based on a specific type of virtual enterprise, One Product Integrated Manufacturing (OPIM). It is a system whose success is based on advanced information and communication technology and a high degree of trust between the partners. A major challenge of an OPIM system lies in its complex application and bureaucratic difficulties, which is why the simulation tools were used in the decision-making process.

Although we are already in the Information Age, there are still no ideal conditions for investing in technological innovation in Brazil, especially where the product life cycle is shorter (Calmanovici, 2011). This, together with the lack of trust between the partners to exchange information (Brettel et al., 2014; Spekman \& Davis, 2016), prevents further research into shared production. Therefore, this paper aims to solve some problems in a way that answers the following questions: (i) What are the benefits of using technological tools to assist decision-making? (ii) What is the best way to plan the route of the product according to productive resources efficiency? (iii) How can the simulation be used in the virtual factories development?

This article aims to explore and enrich available knowledge about virtual enterprises and cooperative production. More specifically, this article seeks to develop a simulation-optimization model that allows the identification of the most efficient configuration of a system of shared production based on virtual factories.

The paper follows this structure: The section "literature review" deals with the concepts of shared production, virtual factories and OPIM. The section "research methodology" explains how the simulation optimization tool works. In the section 
"simulation-based analysis" simulations of test cases of enterprise networks are presented. In the first case, customers stochastically select which of the three competing manufacturers in the same region produces the product. In the latter case, the three manufacturers share productive resources under the same brand and how their resources are used is determined by simulation-based optimization. After the analysis of the process capacity, a study is made on the transportation capacity of the products between the factories. Finally, the concluding considerations and suggestions for future work are discussed in the "Conclusion" section.

\section{Literature review}

According to Putnik \& Silva (1995), factories designed to produce several products are technically less efficient compared to factories dedicated to a single product where its performance reaches its maximum. Based on this premise, the concept of One Product Integrated Manufacturing (OPIM), an organizational concept for manufacturing systems to optimize the manufacture of a particular product, is developed. It is a recent idea in relation to other manufacturing systems and examines some characteristics of extended, agile and virtual enterprises in order to maximize efficiency and production capacity.

The first chart in Figure 1 shows that performance in a traditional factory varies from product to product depending on how resources are used. The second chart presents the proposal of an OPIM system, where each product has its own factory with optimized performance due to the use of dedicated resources. These dedicated factories are called "virtual factories" because of their temporary and variable organization (Pithon, 2004).
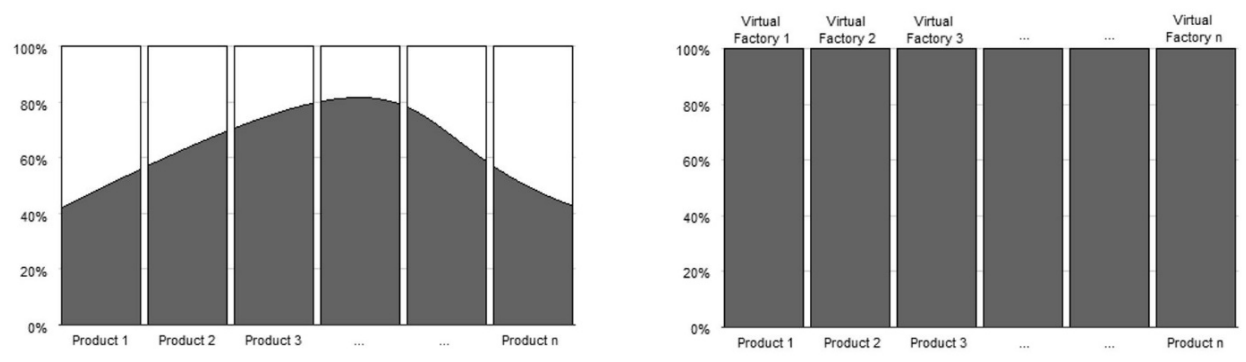

Figure 1. Performance comparison between multiproduct factories and OPIM factories. Source: Putnik \& Silva (1995).

The processes responsible for producing the product can be divided into tasks or elements that can be reorganized more efficiently. These so-called "primitive resources", can be distributed globally in different enterprises and form a network of enterprises that connects their primitive resources through a technology of data transmission (Cunha \& Putnik, 2006). The set of enterprises and their primitive resources is called the "domain". The wider the domain span, the wider the range of possible solutions for a product, but better decision support technologies in more complex structures and real time reconfigurations are also needed (Putnik \& Silva, 1995). Figure 2 demonstrates the process of selecting the primitive resources of a domain to form a set of virtual factories, each dedicated to one product - an OPIM system. 


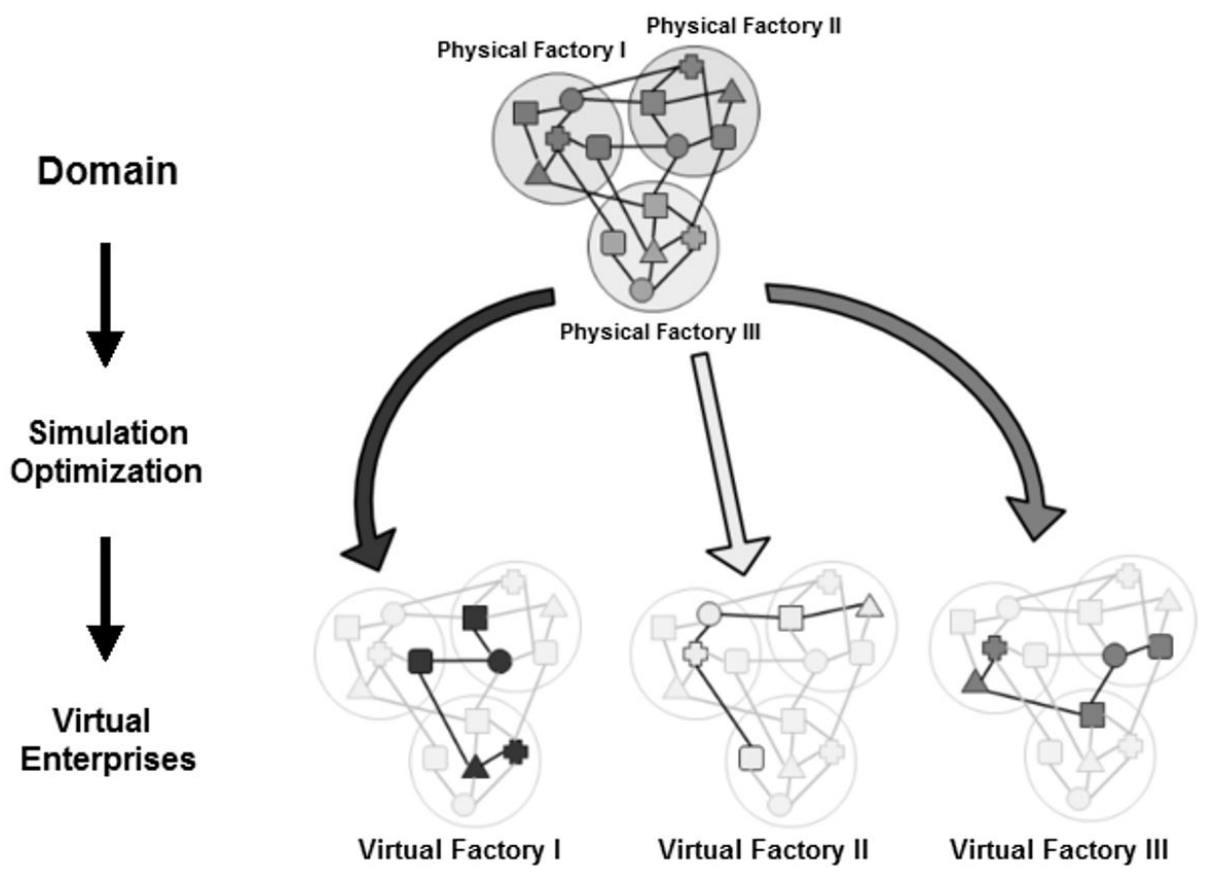

Figure 2. Primitive resources selection for OPIM systems. Source: Adaptado de Cunha \& Putnik (2006).

Putnik \& Silva (1995) states that each primitive resource cell is specialized in one kind of service - design, planning, management, and manufacturing - and that the OPIM system output must have the best performance for the product within the set of possible cells. With the use of information technology, the design, planning and management functions are independent of the distance between the resources.

Advantages of an OPIM system for enterprises include the dynamic reengineering of business processes and the strengthening of competitiveness through access to new resources, services and knowledge of other enterprises within the network, as well as decentralization and better distribution of the business. Microenterprises and individual entrepreneurs can benefit from OPIM by integrating into networks of larger companies, taking advantage of the logistics and production chain to develop even when they're installed in factories of low investment. Many small businesses dedicated to every primitive resource of the product can offer lower prices and higher product quality, competitiveness and flexibility. However, OPIM systems face a number of difficulties, including legal and economic problems, intellectual property, real-time applications of technology and information tools, and the transformation of enterprise knowledge (Putnik \& Silva, 1995).

Putnik \& Silva (1995) briefly mention the advantages of an OPIM system for individual entrepreneurs, but they do not clearly mention the advantages for large companies of having micro entrepreneurs in their network. Smaller companies tend to focus more on core business, making their activities more efficient. Large companies do not have the same productive efficiency but compensate with large networks of relationship and supply chains. The OPIM system proposes to use companies of any size by integration without physical barriers. Smaller companies have greater efficiency but find it difficult to produce and distribute the complete product. The largest company in the network will usually act as the link between the resources and, in return, achieve 
more efficient production and of better quality through cooperation between the partners involved. If every physical enterprise focuses on the micro-objective of improving its activities, macro-objective of the virtual enterprise is achieved when the information circulating through the links between resources is synchronized in real time.

\section{Research methodology}

Figure 3 below shows how the optimization process of an OPIM model based on simulation is performed. Once the primitive resources of the three factories have been identified, the simulation software rearranges these resources by creating a virtual factory for each product and calculates the service level of the factory. This simulation process takes only a fraction of a second to complete, and when it is finished, resources are rearranged in another configuration and a new level of demand fulfillment is calculated.

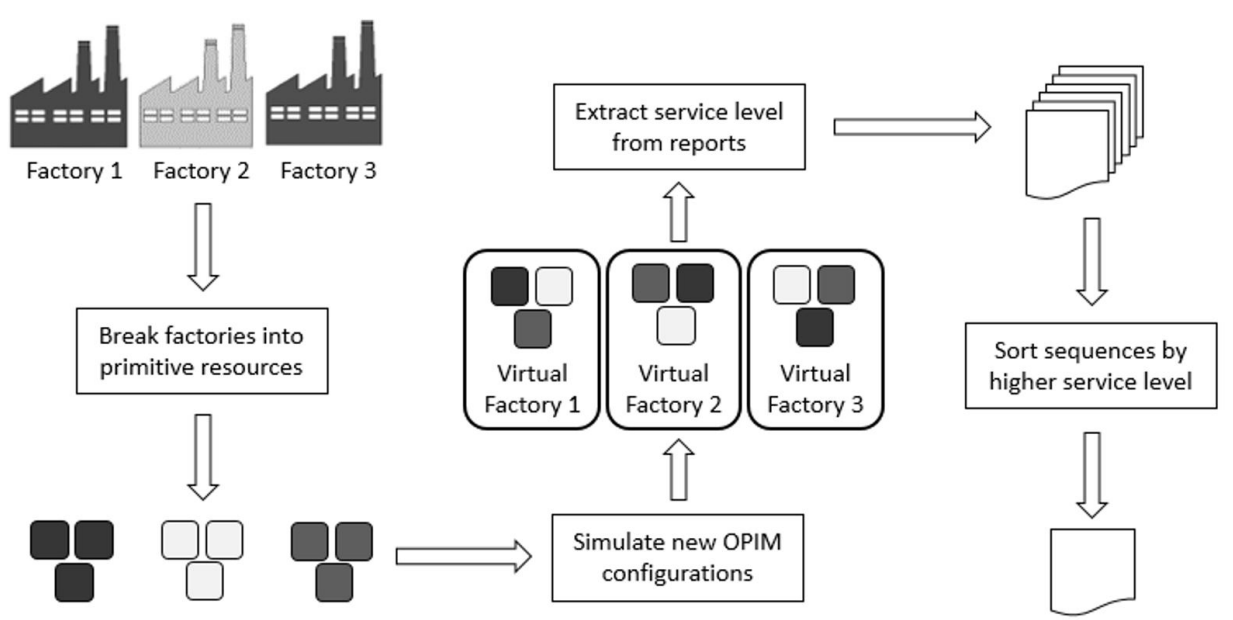

Figure 3. Conceptual procedure of the simulation-based optimization process of a collaborative manufacture. Source: Authors (2016).

These iterations aim to test all possible configurations of virtual factories before selecting one of them for actual implementation. The analysis of the outcome reports identifies important indicators for improvement, such as service level and capacity utilization of each scenario, as well as some variables that impact the values of these indicators.

\section{Simulation-based analysis}

Studying the literature, we see that technological dependence is mentioned in all research on virtual enterprises. The level of online communication and computer processing capacity has grown rapidly in recent decades at a rate of $58 \%$ per year (Hilbert \& López, 2011), making it easier to simulate a virtual factory in real time within a broad resource domain and tracking individual products along the process chain (Brettel et al., 2014), being applied in areas such as transportation, intelligent manufacturing, aviation, critical infrastructures, etc. (Wang et al., 2015). 
Simulation has been an important ally in the development of Industry 4.0, where manufacturing and logistics processes are monitored and controlled by computers through the integration of physical and virtual elements (Lee et al., 2015). Industry 4.0 technological innovations will soon lead to reduced transportation and communication costs and increased efficiency and productivity throughout the supply chain, opening new market opportunities. They will create new ways to meet existing needs and break the old industrial value chain (Schwab, 2016).

The system studied in this paper consists of three factories producing a line of three products and each product has an end customer and a supplier of raw material, as shown in Figure 4. Before becoming a finished product, the raw material needs to undergo three distinct processes that can be carried out in any of the three factories. All suppliers own their vehicle to transport the raw material to the factories, just as each factory has a vehicle to transport the finished product to the customer and possibly semi-finished products between the factories.

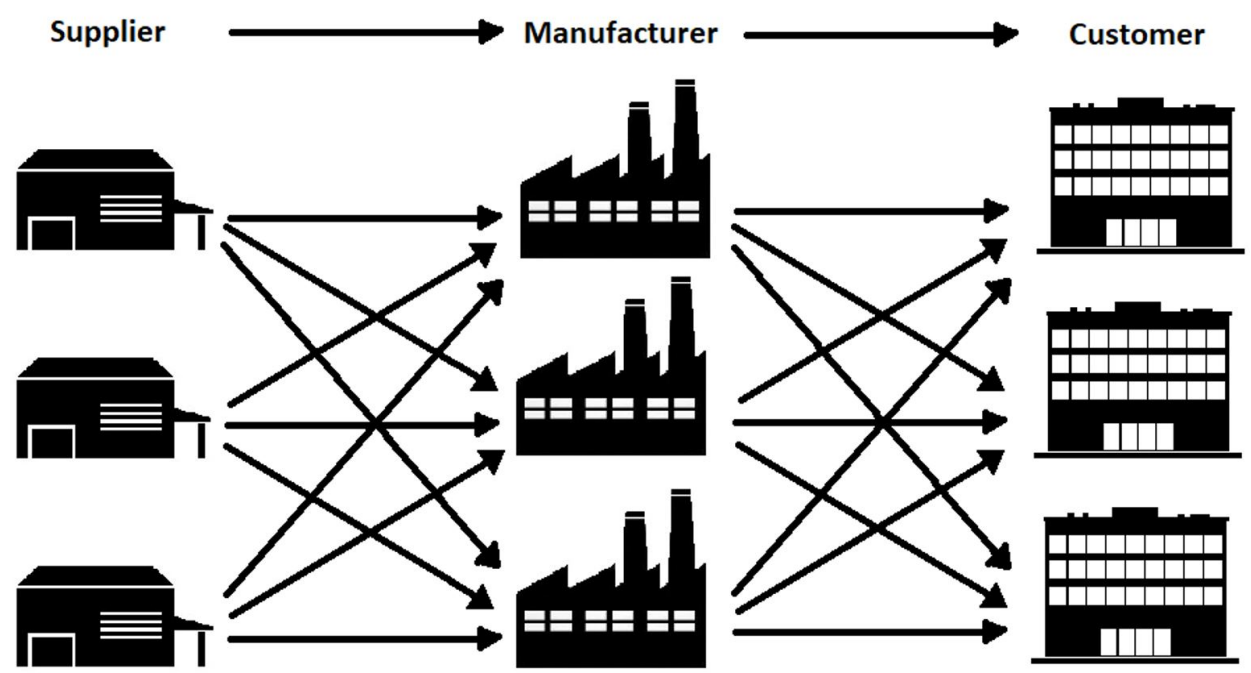

Figure 4. Conceptual model. Source: Authors (2016).

The relevant factor for the analysis is that one factory has specialties and competencies different from the others, which means that a specific process can be more efficient in a given factory or a factory may have more experience in a particular stage of the manufacture of a product. Collaborative production systems are designed to exploit partner expertise and maximize productive efficiencies, so the simulation of systems aims to identify the most efficient way to exploit these resources.

The process simulation also considers the stochastic variables of the system. In this case, stochasticity is present in the process time of the products, the demand and the travel time of the vehicles. Even if the time between one order and another is equal to the average process time of these orders, bottlenecks and idle periods prevent the production system from being able to meet demand.

In order to test the efficiency of shared production systems, the following two models will be simulated and compared. 


\section{Traditional competitive system}

In this model, customers randomly choose a manufacturer who will be responsible for all three processes in that batch of products. That is, a factory is completely independent of the others and its main concern is to meet the stochastic demand.

This can be seen as a traditional model where the three manufacturers compete within the same market and are responsible for manufacturing their entire product mix. Although they are producing the same products with the same quality, the different competences of each manufacturer generate different levels of productive efficiency. There are three suppliers and customers in this example, one for each specific product, but modeling a supply chain with a larger or smaller number of suppliers and customers follows the same programming logic. The biggest difference would be the routes that the vehicles choose would have different distances, impacting on the availability of the vehicles and, consequently, the capacity of service of the manufacturers. Itis possible to change the quantity of manufacturers, vehicles and types of products as well, depending on the needs of the study.

\section{Optimized shared production system}

The following model has the goal of analyzing the behavior of a cooperative production system in which the three manufacturers operate under the same brand. This cooperative model has the same inputs as the traditional competitive model, with the exception of the production sequence. While in the traditional model the product follows through the three processes of the factory chosen by the customer, in the cooperative model the products follow a specific route and can pass through any of the three manufacturers. This routing seeks to optimize service level, having as restrictions the capacity of production and transportation of resources.

\section{Production data}

Production data is added after the virtual model is built. First, the productive efficiency of the processes for each product and each plant is added, as shown in Table 1.

Table 1. Average process time of a batch of products in hours.

\begin{tabular}{ccccc}
\hline & & Product 1 & Product 2 & Product 3 \\
\hline & Process 1 & 1.10 & 1.08 & 1.49 \\
\hline Factory 1 & Process 2 & 0.71 & 0.70 & 0.96 \\
\hline & Process 3 & 1.16 & 1.14 & 1.56 \\
\hline & Process 1 & 1.98 & 2.03 & 1.49 \\
\hline Factory 2 & Process 2 & 0.71 & 0.73 & 0.53 \\
\hline & Process 3 & 1.11 & 1.14 & 0.83 \\
\hline Factory 3 & Process 1 & 1.98 & 1.08 & 1.43 \\
\hline & Process 2 & 1.34 & 0.73 & 0.96 \\
\hline & Process 3 & 1.16 & 0.63 & 0.83 \\
\hline
\end{tabular}

Source: Authors (2016). 
This paper uses the order fulfillment rate as a function of takt time as a comparison parameter. Being takt time the available production time divided by the average number of orders, the attendance rate is the percentage of these orders that are delivered to the final customer. Therefore, the values in Table 1 are in hours per batch.

The higher the value in the table, the larger the number of batches that can be processed in that step, so some trends in the values are visible. Process 1 tends to be faster while Process 2 is the slowest, Factory 1 produces Product 3 with better efficiency while Factory 3 is more efficient in the manufacture of Product 1 , among other trends.

\section{Mathematical modeling}

All mathematical operations presented in this subchapter are performed automatically by the software during the simulation process or are used for analysis of reports in spreadsheets.

The first step in mathematical modeling is to define the main objective of the model. In this scenario, the main objective is to maximize the customer service level of the system, as shown in the Equation 1. Considering the following variables, the optimization objective is found in the equation below.

$p$ Process;

$P$ Amount of required processes to manufacture the product;

$q$ Product;

$Q$ Amount of distinct products.

$r_{p q}$ Primitive resource, identification of the factory responsible for carrying out the product $\mathbf{p}$ process $\mathbf{q}$;

$R$ Amount of manufacturers able to carry out product $\mathbf{p}$ process $\mathbf{q}$.

$n$ Product units;

$z$ Objective function, overall service level of the system.

$D$ Route;

$d$ Route D lenght;

$v$ Vehicle;

$s_{V}$ Vehicle $\mathbf{v}$ speed;

$m_{v d}$ Total of times vehicle $\mathbf{v}$ completed route $\mathbf{D}$.

$\max z=\frac{\sum_{I}^{Q}{\text { Product } \text { output }_{q}}^{Q}}{\sum_{I}^{Q} \text { Rawmaterial input }_{q}}$

The count of products entering and exiting the system begins after a warm-up period, which is a period after the start of the simulation in which the statistics are deleted. In other words, the initial statistics during the warm-up period are deleted, but the simulation continues from its current state. This tool is useful for removing atypical system conditions that occur when no entities are present.

Table 2 is the generic form of the production sequence of the system. In the theoretical scenario studied during this work, the production sequence table has 3 processes $\mathbf{p}$ represented in the rows, 3 products $\mathbf{q}$ for the columns and primitive resources $\mathbf{r}$ within each cell with a value of 1 to 3 representing the factory that will be performed process. Equation 2 generates a unique code for each configuration during 
the simulation-optimization process. This value ranges from $\# 00000$ to \#19682, which is the maximum number of possible configurations.

Table 2. Generic model of the production sequence table.

\begin{tabular}{cccc}
\hline \#Sequence & Product 1 & Product 2 & Product 3 \\
\hline Process 1 & $r_{11}$ & $r_{12}$ & $r_{13}$ \\
\hline Process 2 & $r_{21}$ & $r_{22}$ & $r_{23}$ \\
\hline Process 3 & $r_{31}$ & $r_{32}$ & $r_{33}$ \\
\hline
\end{tabular}

Source: Authors (2016).

Sequence $=\sum_{I}^{P} \sum_{I}^{Q}\left(r_{p q}-1\right) * 3^{(p-l)+3 *(q-I)}$

The model uses the takt time of products to define the rate at which entities (batches of products) are generated in the systemAlthough "demand" is a more common parameter in the literature, the two terms are directly linked to simple equality, as shown in Equations 3 and 4 . The takt time is the average time that a certain quantity of products enters the system, while the demand is the average quantity of products entering the system within a given period. Therefore, in order for the system to meet $100 \%$ of the demand, the takt time of a product q must be greater than the cycle time of all the processes $\mathbf{p}$ of the product $\mathbf{q}$.

Takt time $=$ Demand $^{-1}$

Takt time $_{q} \geq$ Cycletime $_{p q}$

Equations 5 and 6 represent the two main constraints of the system, which are production capacity and transport capacity. In order for $100 \%$ of the demand to be met, the sum of the capacities that all plants have to carry out the processes $\mathbf{p}$ must be greater than the total of products $\mathbf{q}$ that will perform the processes $\mathbf{p}$ times their cycle time. For all batches of products to be transported without delay, the vehicle carrying capacity $\mathbf{v}$ must be greater than twice the total distance traveled (number of trips times the distance of the journeys) on the average speed of the vehicle $\mathbf{v}$.

$$
\begin{aligned}
& \sum_{l}^{R} \text { Capacity }_{r p} \geq \sum_{l}^{Q} n_{q} \times \text { Cycletime }_{p q} \\
& \text { Capacity }_{v} \geq 2 \times \sum_{l}^{D} \frac{m_{v d} \times d}{\overline{s_{v}}}
\end{aligned}
$$

\section{The problem of production capacity}

Table 1 above shows the batch process times in the factories in hours, while the first column of Figure 5 below shows the takt time in hours per batch. These data are used as input in the simulation model which, from 1,000 iterations per scenario, has resulted in the service level for the simulated demand levels. 
As shown in the second column of Figure 5, for the traditional competitive model, more than $99 \%$ of orders from that period are met if the takt time of each product is 2.5 hours per batch. The period used in the simulation was five days, plus an extra warm-up day.

Costumer service level

\begin{tabular}{lll}
\hline Takt Time & Traditional & Optimal \\
1.00 & $52.4 \%$ & $78.3 \%$ \\
1.25 & $65.3 \%$ & $90.4 \%$ \\
1.50 & $78.0 \%$ & $96.4 \%$ \\
1.75 & $87.6 \%$ & $98.8 \%$ \\
2.00 & $94.6 \%$ & $99.5 \%$ \\
2.25 & $97.5 \%$ & $99.8 \%$ \\
2.50 & $99.1 \%$ & $100 \%$
\end{tabular}

Figure 5. Costumer service level as a function of takt time. Source: Authors (2016).

In the shared manufacturing model, an optimization was done using OptQuest, an add-in to the Simio Simulation software, which manipulates control parameters linked to the production sequence to identify the best alternative among the thousands of different scenarios generated.

This simulation-based optimization process identified that the sequence with code $\# 12285$ has the best customer service level for scenarios where all three products have the same takt time. Sequence \#12285 can be seen below in Table 3, while Figure 5 shows the comparison of the traditional three-competitor system against a threepartner virtual enterprise following production plan \#12285.

Table 3. Production sequence \#12285.

\begin{tabular}{cccc}
\hline \#12285 & Product 1 & Product 2 & Product 3 \\
\hline Process 1 & Factory 1 & Factory 3 & Factory 2 \\
\hline Process 2 & Factory 1 & Factory 2 & Factory 3 \\
\hline Process 3 & Factory 1 & Factory 3 & Factory 2 \\
\hline
\end{tabular}

Source: Authors (2016).

Since Factory 1 had shorter process time for Product 1 than the other two factories, optimization looked for sequences that dedicated Factory 1's production capacity to Product 1. For the other two products, none of the factories had an efficiency of consistent production in all three processes, it is therefore more advantageous to transport the semi-finished product to the factory which carries out the next process more efficiently.

In an OPIM system, each production step (or primitive resource) can be studied as a subsystem independent of the other resources. Table 4 below shows the average times in hours that the semi-finished products waited in the machine buffer before being processed, taken from the simulation report. These waiting times are a consequence of long process times, previously seen in Table 1, because longer processes tend to generate bottlenecks in pre-process inventories. 
Table 4. Average waiting time of products in buffer (in hours).

\begin{tabular}{cccc}
\hline & & Tradicional & Optimal \\
\hline Factory 1 & Process 1 & 3.09 & 5.33 \\
\hline & Process 2 & 1.12 & 2.56 \\
\hline & Process 3 & 2.74 & 4.17 \\
\hline Factory 2 & Process 1 & 8.10 & 7.30 \\
\hline & Process 2 & 0.52 & 0.36 \\
\hline Factory 3 & Process 3 & 1.07 & 0.98 \\
\hline & Process 1 & 5.05 & 4.60 \\
\hline & Process 2 & 1.75 & 0.47 \\
\hline
\end{tabular}

Source: Authors (2016).

It is noted that the buffer of Process 1 of Factory 2 is where the products wait the most until they are processed, because they have longer process times (or in other words, less productive capacity).

Taking advantage of the ease of the simulation software in testing different scenarios, a new test was made with a change in the model to reduce the waiting time before Process 1 of Factory 2. In this test, whose average result of 1,000 iterations is in Table 5, two entities can perform Process 1 of Factory 2 at the same time, as if a second machine were acquired, effectively doubling the productive capacity.

Table 5. Average waiting time after increasing Factory 2 Process 1 capacity.

\begin{tabular}{cccc}
\hline & & Tradicional & Optimal \\
\hline Factory 1 & Process 1 & 4.11 & 5.33 \\
\hline & Process 2 & 1.61 & 2.48 \\
\hline & Process 3 & 3.47 & 4.13 \\
\hline Factory 2 & Process 1 & 1.67 & 1.34 \\
\hline & Process 2 & 1.27 & 0.42 \\
\hline Factory 3 & Process 3 & 2.06 & 2.13 \\
\hline & Process 1 & 6.88 & 4.63 \\
\hline & Process 2 & 2.28 & 0.95 \\
\hline
\end{tabular}

Source: Authors (2016).

Comparing the old results in Table 3 with the results of the capacity improvement in Table 5 , there was a reduction of approximately $80 \%$ of the average wait time in the first Factory 2 process buffer in both the standard scenario and the optimized scenario. The main difference is that in the default scenario, all other eight processes had an increase in buffer timeout, whereas in the OPIM system scenario the wait time before Process 1 of Factory 2 had a significant reduction without changing the size of the buffers of other processes.

This is a reflection of the independence of dedicated machines. When a bottleneck is disposed of in a traditional production system, in spite of an overall improvement in 
the capacity to meet demand, there is an increase in the flow of products within the plant and consequently a greater effort of the other processes to support that flow.

A similar phenomenon observed in this test is the increase in the service level by type of product, whose data are shown in Table 6 below. In both scenarios, the sum of the average attendance rate of the three products is approximately $30 \%$, but in the standard system this increase was divided among the three products, since all the factories are responsible for the production of all the products. Increasing the capacity of only one process affects all others.

The opposite is observed in the OPIM system, because as Process 1 of Factory 2 was dedicated to the production of Product 3 , the $30 \%$ increase in the attendance rate was concentrated in Product 3.

Table 6. Service level by product type.

\begin{tabular}{ccc}
\hline \multirow{2}{*}{ Product } & \multicolumn{2}{c}{ Original capacity } \\
\cline { 2 - 3 } & Tradicional & Optimal \\
\hline Product 1 & $52.3 \%$ & $79.2 \%$ \\
\hline Product 2 & $51.7 \%$ & $89.1 \%$ \\
\hline Product 3 & $52.0 \%$ & $67.4 \%$ \\
\hline \multirow{2}{*}{ Increased capacity } \\
\hline Product & \multicolumn{2}{c}{ Optimal } \\
\cline { 2 - 3 } & \multicolumn{3}{c}{ Tradicional } & $79.7 \%$ \\
\hline Product 1 & $62.4 \%$ & $87.2 \%$ \\
\hline Product 2 & $62.7 \%$ & $98.1 \%$ \\
\hline Product 3 & $62.2 \%$ &
\end{tabular}

Source: Authors (2016).

\section{The problem of transportation capacity}

From the information of the previous subchapter on the problems of the productive capacity, we can make some conclusions about the capacity of transport of the products between plants and the balancing of all operations of the chain.

In some scenarios, it is best to send semi-finished products to be processed in another factory because of idle vehicles and process overload. Better utilization of the available capacity of the vehicles alleviates the factory's productive capacity, balancing the system as a whole.

During previous simulation processes, there was a distance of ten kilometers between suppliers and factories and between factories and distribution centers for the customers. The three factories were about five kilometers apart, while the six dedicated vehicles (one for each supplier and one for each manufacturer) were traveling at an average speed of sixty kilometers per hour. According to the original definition of Michael Porter (1990), all partners in the chain are relatively close enough to each other so that this group can be defined as a cluster.

In order to expand the analysis of the geographic proximity of chain members, a series of simulations were performed comparing sequence \#12285, obtained earlier, with sequence \#10179, shown in Table 7, which follows the same logic of dedicating primitive resources to the manufacture of products that have the highest efficiency, but 
avoiding to the maximum the transportation of semi-finished products between manufacturers.

Table 7. Production sequence \#10179.

\begin{tabular}{cccc}
\hline$\# \mathbf{1 0 1 7 9}$ & Product $\mathbf{1}$ & Product $\mathbf{2}$ & Product $\mathbf{3}$ \\
\hline Process $\mathbf{1}$ & Factory $\mathbf{1}$ & Factory $\mathbf{3}$ & Factory $\mathbf{2}$ \\
\hline Process $\mathbf{2}$ & Factory $\mathbf{1}$ & Factory $\mathbf{3}$ & Factory $\mathbf{2}$ \\
\hline Process $\mathbf{3}$ & Factory $\mathbf{1}$ & Factory $\mathbf{3}$ & Factory $\mathbf{2}$ \\
\hline
\end{tabular}

Source: Authors (2016).

In this analysis a greater than previous transport period was simulated. The results are based on four parameters:

1. Transport time from factories to suppliers and distribution centers, ranging from 0.2 to 2.0 hours in transit;

2. Transport time between manufacturers, which also vary from 0.2 up to 2.0 hours;

3. Demand for products, which have a takt time ranging from 1.0 to 2.5 hours per lot for each product;

4. Production plan OPIM, where Product 2 and Product 3 change manufacturer during sequence \#12285, but remain in the same factory during sequence \#10179.

According to the results drawn from the reports, it can be concluded that even if a process is inefficient, the simulation software suggests that the batch should be manufactured entirely in the same factory if there are not enough vehicles to carry the transport or its vehicles are overloaded.

With this in mind, it is possible to explore the functionality of this simulation-based optimization tool to define the maximum distance between plants that compensates for the transportation of the semi-finished product. For this, it is necessary to study the simulation reports to identify an equilibrium curve, as exemplified in Figure 6, where one production plane may be better than the other depending on the position in relation to the curve.

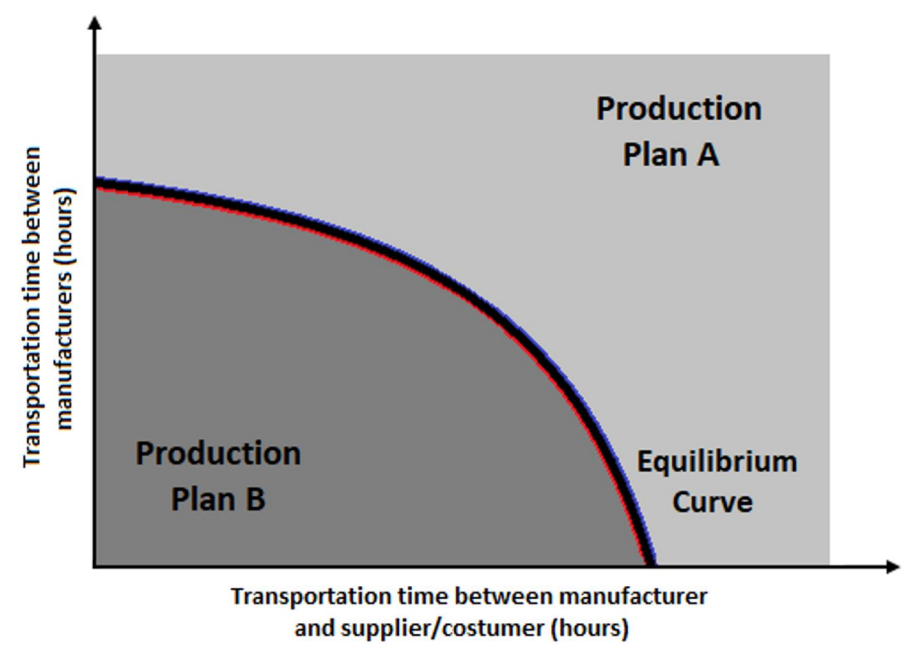

Figure 6. Comparison of two production plans as a function of transportation time. Source: Authors (2016). 
One of the most important indicators of transport performance is the vehicle utilization rate. Tables 8 and 9 below can be used to compare the OPIM system with the traditional one and to study the impact of geographical proximity on the model. The tables show the utilization rate of the six vehicles in the system at a takt time of 1.5 hours per batch of products, with the distance between suppliers and factories varying from 0.2 to 2.0 hours.

Table 8. Utilization rate of vehicles in an OPIM system.

\begin{tabular}{lcccccccccc}
\hline \multicolumn{1}{c}{ Length (h) } & $\mathbf{0 . 2}$ & $\mathbf{0 . 4}$ & $\mathbf{0 . 6}$ & $\mathbf{0 . 8}$ & $\mathbf{1 . 0}$ & $\mathbf{1 . 2}$ & $\mathbf{1 . 4}$ & $\mathbf{1 . 6}$ & $\mathbf{1 . 8}$ & $\mathbf{2 . 0}$ \\
\hline Supplier 1 & $24.4 \%$ & $42.6 \%$ & $73.4 \%$ & $94.4 \%$ & $98.1 \%$ & $99.0 \%$ & $99.3 \%$ & $99.5 \%$ & $99.6 \%$ & $99.7 \%$ \\
\hline Supplier 2 & $37.9 \%$ & $50.4 \%$ & $72.3 \%$ & $93.9 \%$ & $98.7 \%$ & $99.7 \%$ & $99.8 \%$ & $99.9 \%$ & $99.9 \%$ & $100 \%$ \\
\hline Supplier 3 & $16.8 \%$ & $41.6 \%$ & $63.9 \%$ & $93.4 \%$ & $97.3 \%$ & $98.3 \%$ & $99.3 \%$ & $99.2 \%$ & $99.5 \%$ & $99.7 \%$ \\
\hline Manufacturer 1 & $14.0 \%$ & $32.2 \%$ & $57.0 \%$ & $79.4 \%$ & $84.3 \%$ & $86.6 \%$ & $87.0 \%$ & $86.5 \%$ & $85.7 \%$ & $85.5 \%$ \\
\hline Manufacturer 2 & $15.0 \%$ & $34.2 \%$ & $65.1 \%$ & $81.6 \%$ & $87.0 \%$ & $86.7 \%$ & $87.5 \%$ & $85.9 \%$ & $86.1 \%$ & $85.3 \%$ \\
\hline Manufacturer 3 & $15.5 \%$ & $38.6 \%$ & $59.4 \%$ & $82.7 \%$ & $85.6 \%$ & $87.1 \%$ & $86.1 \%$ & $86.5 \%$ & $84.7 \%$ & $84.8 \%$ \\
\hline
\end{tabular}

Source: Authors (2016).

Table 9. Utilization rate of vehicles in a traditional system.

\begin{tabular}{lcccccccccc}
\hline \multicolumn{1}{c}{ Length (h) } & $\mathbf{0 . 2}$ & $\mathbf{0 . 4}$ & $\mathbf{0 . 6}$ & $\mathbf{0 . 8}$ & $\mathbf{1 . 0}$ & $\mathbf{1 . 2}$ & $\mathbf{1 . 4}$ & $\mathbf{1 . 6}$ & $\mathbf{1 . 8}$ & $\mathbf{2 . 0}$ \\
\hline Supplier 1 & $52.1 \%$ & $66.4 \%$ & $86.9 \%$ & $94.7 \%$ & $97.7 \%$ & $98.7 \%$ & $99.3 \%$ & $99.5 \%$ & $99.1 \%$ & $99.6 \%$ \\
\hline Supplier 2 & $55.4 \%$ & $64.2 \%$ & $85.3 \%$ & $93.2 \%$ & $98.4 \%$ & $98.8 \%$ & $99.6 \%$ & $98.9 \%$ & $99.2 \%$ & $99.8 \%$ \\
\hline Supplier 3 & $55.8 \%$ & $68.2 \%$ & $85.8 \%$ & $93.8 \%$ & $97.1 \%$ & $97.9 \%$ & $98.8 \%$ & $99.4 \%$ & $99.6 \%$ & $99.4 \%$ \\
\hline Manufacturer 1 & $13.0 \%$ & $31.2 \%$ & $50.7 \%$ & $69.6 \%$ & $77.2 \%$ & $75.9 \%$ & $78.8 \%$ & $76.2 \%$ & $77.9 \%$ & $73.0 \%$ \\
\hline Manufacturer 2 & $13.4 \%$ & $31.6 \%$ & $49.5 \%$ & $70.7 \%$ & $79.8 \%$ & $79.2 \%$ & $80.9 \%$ & $74.8 \%$ & $78.4 \%$ & $79.0 \%$ \\
\hline Manufacturer 3 & $13.5 \%$ & $34.8 \%$ & $58.6 \%$ & $75.3 \%$ & $80.2 \%$ & $83.6 \%$ & $81.6 \%$ & $85.3 \%$ & $80.5 \%$ & $83.1 \%$ \\
\hline
\end{tabular}

Source: Authors (2016)

It is noticeable that as the travel time between suppliers and customers approaches one hour, the capacity of suppliers 'vehicles reaches the limit, consequently limiting the use of manufacturers' vehicles.

The manufacturers' vehicle utilization rate tends to be higher in OPIM systems, even if limited by manufacturers, since better productive efficiency requires better transport performance. The faster the factory finishes production, the less time vehicles need to wait for a batch of finished products.

After the first analysis of the data, an increase in the capacity of the vehicles was proposed in order to study the behavior of systems with more efficient transportation. Figures 7 and 8 show the customer service rate in a model that the vehicles have twice the capacity of the previous test models.

The takt time used in this model was 2.5 hours per batch. X-axis is the transportation time between manufacturer and suppliers/customers (in hours) and $y$-axis is the transportation time between manufacturers (in hours). 


\begin{tabular}{|c|c|c|c|c|c|c|c|c|c|c|}
\hline 1.0 & $80.4 \%$ & $76.9 \%$ & $72.9 \%$ & $70.6 \%$ & $68.9 \%$ & $66.5 \%$ & $64.6 \%$ & $61.8 \%$ & $61.0 \%$ & $59.4 \%$ \\
\hline 9 & $86.1 \%$ & $81.8 \%$ & $79.7 \%$ & $75.8 \%$ & $73.3 \%$ & $70.3 \%$ & $67.3 \%$ & $65.7 \%$ & $63.7 \%$ & $62.5 \%$ \\
\hline 8 & $90.6 \%$ & $87.8 \%$ & $85.4 \%$ & $82.4 \%$ & $78.3 \%$ & $74.5 \%$ & $72.3 \%$ & $69.6 \%$ & $67.9 \%$ & $65.9 \%$ \\
\hline 0.7 & $92.9 \%$ & $92.3 \%$ & $90.5 \%$ & $86.5 \%$ & $84.3 \%$ & $79.7 \%$ & $77.7 \%$ & $73.7 \%$ & $71.6 \%$ & $69.5 \%$ \\
\hline 0.6 & $94.5 \%$ & $94.4 \%$ & $93.2 \%$ & $91.0 \%$ & $88.8 \%$ & $84.0 \%$ & $81.9 \%$ & $78.4 \%$ & $76.7 \%$ & $74.7 \%$ \\
\hline 0.5 & $95.6 \%$ & $94.6 \%$ & $94.1 \%$ & $93.4 \%$ & $91.3 \%$ & $89.9 \%$ & $87.3 \%$ & $83.4 \%$ & $81.4 \%$ & $77.4 \%$ \\
\hline 0.4 & $95.3 \%$ & $95.4 \%$ & $95.1 \%$ & $94.7 \%$ & $94.1 \%$ & $92.3 \%$ & $90.9 \%$ & $88.7 \%$ & $85.6 \%$ & $81.6 \%$ \\
\hline 0.3 & $96.2 \%$ & $95.8 \%$ & $95.5 \%$ & $95.4 \%$ & $94.5 \%$ & $94.0 \%$ & $93.1 \%$ & $91.8 \%$ & $88.9 \%$ & $85.4 \%$ \\
\hline 0.2 & $96.3 \%$ & $96.3 \%$ & $96.0 \%$ & $95.7 \%$ & $94.8 \%$ & $94.6 \%$ & $93.7 \%$ & $92.7 \%$ & $91.1 \%$ & $89.8 \%$ \\
\hline \multirow[t]{2}{*}{0.1} & $96.8 \%$ & $96.6 \%$ & $96.6 \%$ & $96.1 \%$ & $95.3 \%$ & $94.9 \%$ & $94.4 \%$ & $94.1 \%$ & $92.9 \%$ & $91.1 \%$ \\
\hline & 0.1 & 0.2 & 0.3 & 0.4 & 0.5 & 0.6 & 0.7 & 0.8 & 0.9 & 1.0 \\
\hline
\end{tabular}

Figure 7. Customer service level of sequence \#12285 considering increased vehicle capacity. Source: Authors (2016).

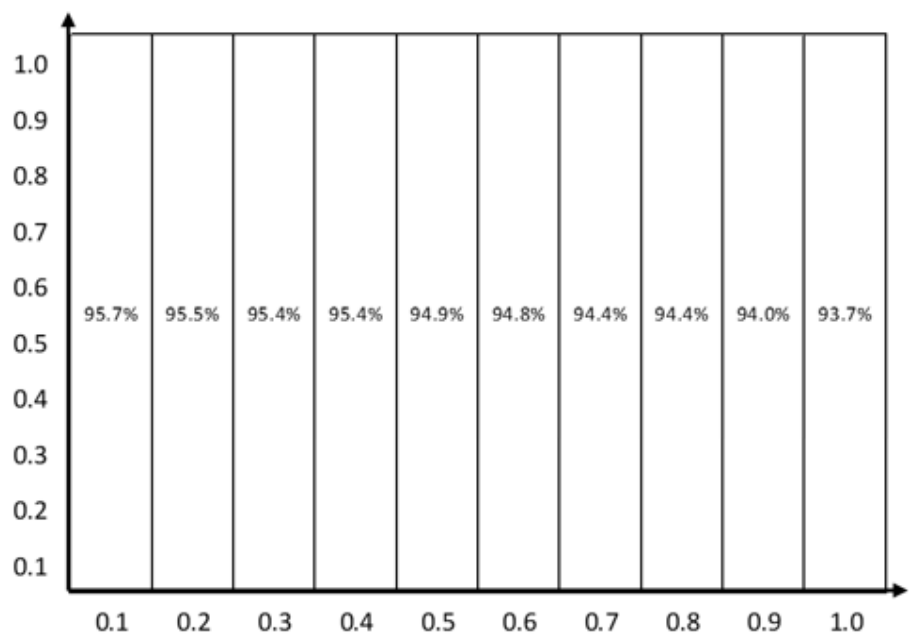

Figure 8. Customer service level of sequence \#10179 considering increased vehicle capacity. Source: Authors (2016).

Analyzing the percentage values from the graphs, it can be noted that up to a certain point the attendance rate does not have significant differences. The capacity of the vehicles has a greater impact in scenarios where the distance between the factories is also greater. This means that, as anticipated, within a certain margin, the production chain will be limited by production capacity and the simulation software will suggest a production sequence that prioritizes efficient processes. Outside this margin, where distances between facilities are higher, the software will suggest a sequence that avoids transportation between manufacturers.

Figure 9 below is an overlap of Figures 7 and 8 which shows which is the best option as a function of transport times, forming the equilibrium curve. 


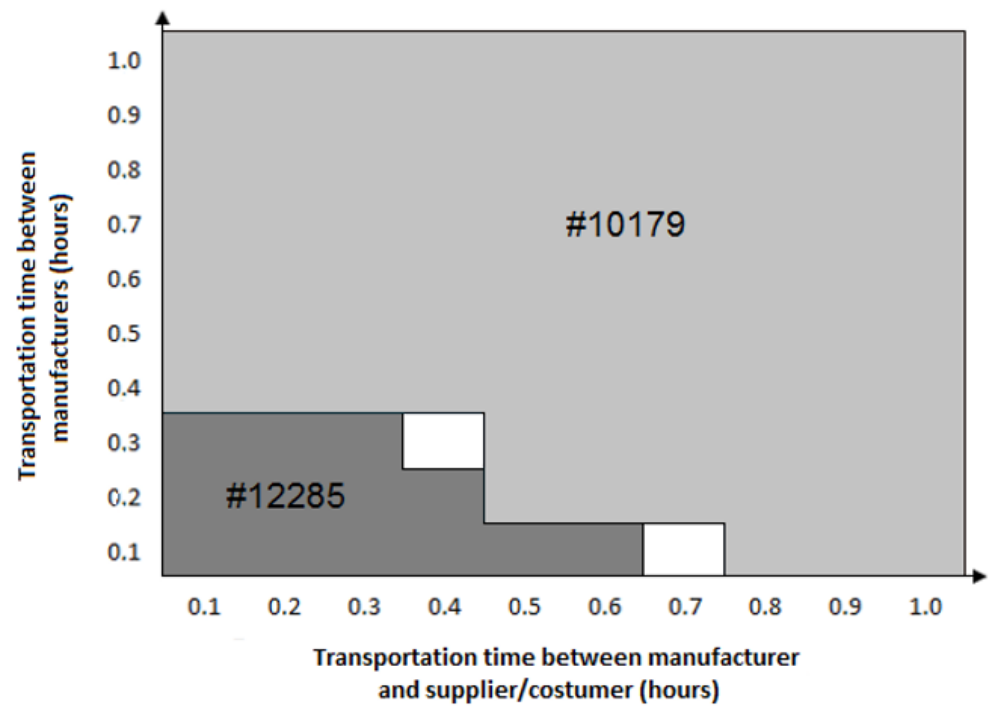

Figure 9. Sequences \#12285 and \#10179 comparison curve considering increased vehicle capacity. Source: Authors (2016).

\section{Conclusions}

The main purpose of process simulation is to acquire knowledge without the need for empirical analysis and to provide an alternative solution that is more expensive and/or less accurate tools. This allows the study of highly complex concepts of application in real systems, such as virtual enterprises that, do not always make possible to develop a real system for academic research, because it demands a high degree of cooperation and other requirements of several different companies.

An effective simulation requires a large knowledge base, gained through case studies, theoretical and analytical publications on the topic under investigation. This knowledge makes it possible to identify the theoretical gaps that will be the subject of research with simulation and to serve as input during the computer-aided modelling process of the system. The richer and more accurate the information, the closer the behavior of the modelled system is to the real one.

Recently, there have been few original publications on the concept of One Product Integrated Manufacturing, probably due to the difficulty of implementing the system, caused by a high level of trust required by the chain members. Over the years, however, the capacity of data transfer, storage and processing computers will increase significantly, facilitating the deployment of systems that require extensive real-time database analysis. Information and documents being transferred in fractions of a second will eliminate the virtual boundary between different companies.

Among the network's primitive resources, other organizations can be added beyond material transformation companies, such as financial, education, or local development support institutions. From an optimization process, parameters such as geographical position, individual efficiency, degree of cooperation and distance from the partners can be used to determine which institutions lead to a higher overall efficiency of the system.

In order to examine the potential flexibility of cooperation, the supply chain must be designed to allow the adjustment of routes and schedules. In order to achieve a very agile system, inventory levels and lead times within the value chain should be reduced. To ensure that consumer needs can still be met safely, a high degree of 
synchronization between organizations is required, so information sharing is indispensable (Brettel et al., 2014).

When comparing the results of the OPIM system with those of the traditional system, it is found that the improvement in the service level is much more significant in scenarios with greater delivery difficulties of delivery or demand. But greater assurance that the orders will be delivered does not necessarily represent lower production costs. There was no solid inventory reduction and the use of transportation vehicles was increased, which reduced their availability.

The computer simulation made it easier to identify a problem in the system and to immediately test a possible correction. The simulation results of the corrected model showed values that could not be predicted with the same ease with other improvement tools. However, in order to identify the best solution to a problem, it is necessary to define which indicators need to be optimized.

The next step in the research is to add financial value to system operations. When resources are tied to manufacturing costs, new indicators can be identified, and the system can be optimized compared to other objectives. The simulation would make it possible to compare the production and transport costs with the costs of delays in delivery (or missed orders) to identify the most profitable route. The use of simulation tools can replace old costing methods, as the software can recognize how much resources each product consumes.

Other elements that can be added to improve the model include scrap and rework rates, production buffer costs, and management of information flow through a broker. Improving the fidelity of the computational model relative to the real one increases the reliability and accuracy of the information, but also requires more computer processing capacity. It is necessary to find the best ratio between accuracy and available time before starting a process simulation.

From a theoretical point of view, another opportunity would be a survey to identify which factors contribute to or hamper the implementation of this system and what actions are necessary for such an implementation to be possible. It is also possible to expand the sample of analyzed virtual enterprises, as well as to carry out interviews and questionnaires with the companies to obtain more data.

\section{References}

Alexander, B., Tatiana, K., \& Svetlana, U. (2013). Formation of industrial clusters using method of virtual enterprises. Procedia Economics and Finance, 5, 68-72. http://dx.doi.org/10.1016/S2212-5671(13)00011-7.

Brettel, M., Friederichsen, N., Keller, M., \& Rosenberg, M. (2014). How virtualization, decentralization and network building change the manufacturing landscape: an industry 4.0 perspective. International Journal of Mechanical, Industrial Science and Engineering, 8(1), 37-44.

Calmanovici, C. E. (2011). A inovação, a competitividade e a projeção mundial das empresas brasileiras. Revista USP, 89(89), 190-203. http://dx.doi.org/10.11606/issn.23169036.v0i89p190-203.

Camarinha-Matos, L. M., \& Afsarmanesh, H. (2013). The virtual enterprise concept. In L. M. Camarinha-Matos \& H. Afsarmanesh. Infrastructures for virtual enterprises: networking industrial enterprises (pp. 3-14). USA: Springer.

Casarotto, N., Fo., \& Pires, L. H. (2001). Redes de pequenas e médias empresas e desenvolvimento local: estratégias para a conquista da competitividade global com base na experiência italiana. São Paulo: Atlas. 
Cunha, M. M., \& Putnik, G. (2006). One product integrated manufacturing. In M. M. Cunha \& G. Putnik. Agile virtual enterprises: implementation and management support (pp. 43-45). Hershey: IGI Global.

Hilbert, M., \& López, P. (2011). The world's technological capacity to store, communicate, and compute information. Science, 332(6025), 60-65. http://dx.doi.org/10.1126/science.1200970. PMid:21310967.

Lee, J., Bagheri, B., \& Kao, H. A. (2015). A cyber-physical systems architecture for industry 4.0based manufacturing systems. Manufacturing Letters, 3, 18-23. http://dx.doi.org/10.1016/j.mfglet.2014.12.001.

Pithon, A. J. C. (2004). Projeto organizacional para a engenharia concorrente no âmbito das empresas virtuais (tese de doutorado). Universidade do Minho, Braga.

Porter, M. E. (1990). The competitive advantage of nations. Harvard Business Review, 68(2), 73-93.

Putnik, G. D., \& Silva, S. C. (1995). One-product-integrated-manufacturing. In L. M. CamarinhaMatos \& H. Afsarmanesh. International Conference on Information Technology for Balanced Automation Systems (pp. 45-52). Boston: Springer.

Santos, L. C., \& Varvakis, G. (1999). Redes de pequenas e médias empresas: organizações virtuais vs. clusters. ENANPAD.

Saraceni, A. V., Resende, L. M. M., Serpe, L. F., \& Andrade, P. P., Jr. (2015). A comparative analysis between clustered and non-clustered companies using innovation indicators. IFAC-PapersOnLine, 48(3), 155-160. http://dx.doi.org/10.1016/j.ifacol.2015.06.074.

Schwab, K. (2016). The Fourth Industrial Revolution: what it means, how to respond. World Economic Forum. Retrieved in 2016, October 22, from https://www.weforum.org/agenda/2016/01/the-fourth-industrial-revolution-what-it-meansand-how-to-respond/

Spekman, R., \& Davis, E. W. (2016). The extended enterprise: a decade later. International Journal of Physical Distribution \& Logistics Management, 46(1), 43-61. http://dx.doi.org/10.1108/IJPDLM-07-2015-0164.

Tang, D., Zheng, L., Chin, K. S., Li, Z., Liang, Y., Jiang, X., \& Hu, C. (2002). E-DREAM: a webbased platform for virtual agile manufacturing. Concurrent Engineering, 10(2), 165-183. http://dx.doi.org/10.1177/1063293X02010002698.

Wang, L., Törngren, M., \& Onori, M. (2015). Current status and advancement of cyber-physical systems in manufacturing. Journal of Manufacturing Systems, 37(Part 2), 517-527. http://dx.doi.org/10.1016/j.jmsy.2015.04.008. 